\title{
Enhanced Proteolytic Clearance of Plasma A $\beta$ by Peripherally Administered Neprilysin Does Not Result in Reduced Levels of Brain $A \beta$ in Mice
}

\author{
John R. Walker, ${ }^{1}$ Reynand Pacoma, ${ }^{1}$ James Watson, ${ }^{1}$ Weijia Ou, ${ }^{1}$ Juliano Alves, ${ }^{1}$ Daniel E. Mason, ${ }^{1}$ Eric C. Peters, ${ }^{1}$ \\ Hugo D. Urbina, ${ }^{1}$ Gus Welzel, ${ }^{1}$ Alana Althage, ${ }^{1}$ Bo Liu, ${ }^{1}$ Tove Tuntland, ${ }^{1}$ Laura H. Jacobson, ${ }^{2}$ Jennifer L. Harris, ${ }^{1}$ \\ and Andrew M. Schumacher ${ }^{1}$ \\ ${ }^{1}$ Genomics Institute of the Novartis Research Foundation, San Diego, California 92121, and ${ }^{2}$ Nervous System Research, Novartis Institutes for Biomedical \\ Research, CH-4002 Basel, Switzerland
}

Accumulation of $\beta$-amyloid $(\mathrm{A} \beta)$ in the brain is believed to contribute to the pathology of Alzheimer's Disease (AD). $\mathrm{A} \beta$ levels are controlled by the production of $\mathrm{A} \beta$ from amyloid precursor protein, degradation by proteases, and peripheral clearance. In this study we sought to determine whether enhancing clearance of plasma $\mathrm{A} \beta$ with a peripherally administered $\mathrm{A} \beta$-degrading protease would reduce brain $\mathrm{A} \beta$ levels through a peripheral sink. Neprilysin (NEP) is a zinc-dependent metalloprotease that is one of the key A $\beta$-degrading enzymes in the brain. We developed a NEP fusion protein with in vitro degradation of $A \beta$ and a 10 day plasma half-life in mouse. Intravenous administration of NEP to wild-type and APP23 transgenic mice resulted in dose-dependent clearance of plasma A $\beta$. However, this did not correspond to reduced levels of soluble brain $\mathrm{A} \beta$ with treatment up to 5 weeks in WT mice or formic acid-extractable brain $\mathrm{A} \beta$ with 3 month treatment in aged APP23. In contrast, intracranial injection of NEP resulted in an acute decrease in soluble brain $\mathrm{A} \beta$. We found no change in amyloid precursor protein gene expression in mice treated with intravenous NEP, suggesting that the lack of effects in the brain following this route of administration was not caused by compensatory upregulation of $\mathrm{A} \beta$ production. Taken together, these results suggest a lack of a robust peripheral $\mathrm{A} \beta$ efflux sink through which brain amyloid burdens can be therapeutically reduced.

\section{Introduction}

Alzheimer's disease (AD) is the leading cause of dementia in the aging population. Pathological hallmarks of the human disease are the accumulation of $\beta$-amyloid $(\mathrm{A} \beta)$ and formation of amyloid plaques in the brain. $A \beta$ is produced through the cleavage of amyloid precursor protein (APP) by $\beta$ - and $\gamma$-secretases to release soluble $\mathrm{A} \beta$ peptide monomers (Hardy and Selkoe, 2002). Human $\mathrm{A} \beta$ monomers, primarily consisting of 40 and 42 residue peptides, are able to form insoluble fibrils that can subsequently aggregate into plaques (Masters et al., 1985). The equivalent mouse $\mathrm{A} \beta$ peptides, in contrast, contain three amino acid residue substitutions that prevent the formation of plaques, possibly by altering the $\beta$-secretase cleavage site (Jankowsky et al., 2007).

Clearance of $\mathrm{A} \beta$ from the brain is accomplished partially through degradation by amyloid-degrading enzymes such as the zincdependent metalloprotease neprilysin (NEP). NEP-deficient mice

Received July 17, 2012; revised Nov. 5, 2012; accepted Dec. 11, 2012.

Author contributions: J.R.W., W.O., J.A., D.E.M., H.D.U., L.H.J., J.L.H., and A.M.S. designed research; R.P., J.W., W.O., J.A., D.E.M., H.D.U., G.W., A.A., and B.L. performed research; J.W., R.P., J.W., J.A., D.E.M., E.C.P., B.L., T.T., and A.M.S. analyzed data; J.R.W., D.E.M., B.L., L.H.J., and A.M.S. wrote the paper.

We thank Dr. Matthias Staufenbiel for guidance with the amyloid extraction and quantification protocols and Lacey Kischassey and Evelyn Rodrigo for technical assistance.

Correspondence should be addressed to Dr. Andrew M. Schumacher, Genomics Institute of the Novartis Research Foundation, 10675 John Jay Hopkins Drive, San Diego, CA 92121. E-mail: aschumacher@gnf.org.

DOI:10.1523/JNEUROSCI.3407-12.2013

Copyright $\odot 2013$ the authors $\quad 0270-6474 / 13 / 332457-08 \$ 15.00 / 0$ have elevated brain $\mathrm{A} \beta$ levels and a reduced ability to degrade exogenous A $\beta$ (Iwata et al., 2000, Iwata et al., 2001). Furthermore, inhibition of NEP by thiorphan causes increased accumulation of $\mathrm{A} \beta$ and memory impairment (Iwata et al., 2000; Zou et al., 2006). Conversely, increasing neprilysin expression and activity in $\mathrm{AD}$ transgenic mouse models reduces plaque formation (Marr et al., 2003; Saito et al., 2005).

Brain A $\beta$ clearance is also accomplished through efflux into the periphery (Shibata et al., 2000; Zlokovic, 2004; Marques et al., 2009), and it has been hypothesized that a dynamic equilibrium exists between these $\mathrm{A} \beta$ pools. However, this $\mathrm{A} \beta$ efflux appears to be mediated through transporter proteins, the saturation of which may limit the rate and/or degree to which equilibrium can be achieved (Shibata et al., 2000). Despite the sequence differences between human and mouse $\mathrm{A} \beta$ peptides, there is no evidence that the clearance mechanisms differ or that the mouse would be a poor model in which to study the intercompartmental equilibrium of monomeric $\mathrm{A} \beta$.

The equilibrium between brain and peripheral $A \beta$ provides the basis for several anti-A $\beta$ vaccination approaches. Some animal data suggest that sequestration of free peripheral $\mathrm{A} \beta$ monomers shifts the equilibrium toward increased efflux, leading to reduction of central nervous system $\mathrm{A} \beta$ and plaque levels (DeMattos et al., 2001, 2002). This approach has come to be known as the "peripheral sink." However, other data suggest that anti-A $\beta$ antibodies might be crossing the blood-brain barrier 
(BBB) at a low rate, acting directly on the brain $\mathrm{A} \beta$ and amyloid deposits (Levites et al., 2006; Wang et al., 2011). This possibility is supported by reports that the BBB is compromised in APPoverexpressing mice (Paul et al., 2007) as well as in a fraction of AD patients (Bowman et al., 2007).

Clarification of the mechanism of action of peripherally administered therapeutics that reduce brain amyloid load will have important implications for the pharmacokinetic/pharmacodynamic relationship of anti-amyloid therapies. This in turn may impact how such therapies are developed and tested. In this study we report use of recombinant NEP to degrade plasma $\mathrm{A} \beta$, thus allowing us to determine whether a dynamic, nonsaturated equilibrium exists between the peripheral and brain $\mathrm{A} \beta$ pools in mice.

\section{Materials and Methods}

Cloning and production of Fc-NEP. A mouse Fc-fusion construct was created by fusing the extracellular, catalytic domain of mouse NEP (cDNA seq. NM_008604) consisting of residues Y52-W750 to the $\mathrm{C}$-terminal of the mouse $\operatorname{IgG}_{1} \mathrm{Fc}$ region consisting of the amino acid sequence MKTFILLLWVLLLWVPGSTGVAAYPRDCGCKPCICTVPE VSSVFIFPPKPKDVLTITLTPKVTCVVVDISKDDPEVQFSWFVDDV EVHTAQTQPREEQFNSTFRSVSELPIMHQDWLNGKEFKCRVNSAA FPAPIEKTISKTKGRPKAPQVYTIPPPKEQMAKDKVSLTCMITDFFP EDITVEWQWNGQPAENYKNTQPIMDTDGSYFIYSKLNVQKSNWE AGNTFTCSVLHEGLHNHHTEKSLSHSPGK. A second construct containing a PreScission Protease (GE Healthcare) cleavage site between the Fc and NEP sequences was also cloned. Expression of the fusion constructs in the vector is driven by a CMV promoter. Plasmids were transiently transfected using the PEI (polyethylenimine) method (Schlaeger and Christensen, 1999) into FreeStyle 293F cells (Invitrogen) grown in suspension in Freestyle 293 Expression medium (Invitrogen). After 72 h, the media containing secreted Fc-NEP was harvested by centrifugation and filtered before purification.

Fc-NEP was purified using Protein A Sepharose Fast Flow (GE Health-

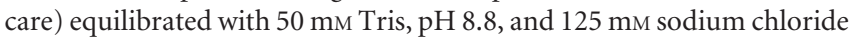
before loading of the media supernatant. Protein was eluted with $100 \mathrm{mM}$ sodium acetate, $\mathrm{pH}$ 5.5, containing $125 \mathrm{~mm}$ sodium chloride. The FcNEP-containing fractions (determined by UV trace) were then further purified by size exclusion on a HiLoad 26/60 Superdex 200 prep grade column (GE Healthcare) equilibrated with Dulbecco's phosphate buffered saline. Fractions containing Fc-NEP, as determined by fluorescent peptide assay activity (described below, NEP activity assays and kinetics) and polyacrylamide gel electrophoresis under nondenaturing conditions, were pooled. To obtain NEP lacking the Fc fusion, the construct containing the PreScission site was taken through the above protocol, followed by cleavage of the Fc domain using immobilized PreScission protease (GE Healthcare).

NEP activity assays and kinetics. Recombinant Fc-NEP activity was quantified using the chromogenic substrate $o$-aminobenzoic acid (Abz)Ala-Glu-Leu-Ala-paranitroaniline (Bachem) in $50 \mathrm{~mm}$ Tris, pH 7.0, containing $125 \mathrm{~mm} \mathrm{NaCl}$ and $0.05 \%$ bovine serum albumin (BSA). Substrate hydrolysis was measured over time on a SpectraMax Gemini plate reader $\left(\lambda_{\mathrm{EX}}=340 \mathrm{~nm}\right.$ and $\left.\lambda_{\mathrm{EM}}=420 \mathrm{~nm}\right)$ (Molecular Devices ). Enzyme kinetics assays were carried out at $37^{\circ} \mathrm{C}$ by varying substrate concentration from 0.06 to $800 \mu \mathrm{M}$ in the presence of $10 \mathrm{nM}$ Fc-NEP. $V_{\max }$ was determined from the fastest part of the resulting progression curve for each substrate concentration.

NEP activity in plasma was determined using a coupled assay in which plasma or recombinant Fc-NEP standard was diluted in assay buffer ( 50 mM Tris pH 7.0, $125 \mathrm{~mm} \mathrm{NaCl}$, and $0.05 \%$ BSA) and incubated with 200 $\mu \mathrm{M}$ glutaryl-Ala-Ala-Phe-4-methoxy- $\beta$-naphthylamide (Sigma) for 5 min at $37^{\circ} \mathrm{C}$. NEP activity was inhibited by addition of the metalloproteinase inhibitor, thiorphan, at $333 \mu \mathrm{M}$ (Sigma). Leucine aminopeptidase (Sigma) was added to a final concentration of $0.58 \mathrm{mg} / \mathrm{ml}$ and fluorescence $\left(\lambda_{\mathrm{EX}}=350 \mathrm{~nm}\right.$ and $\lambda_{\mathrm{EM}}=440 \mathrm{~nm}$ ) was read on a SpectraMax Gemini plate reader.
NEP degradation of $\mathrm{A} \beta_{1-40}$ in buffer was carried out at $37^{\circ} \mathrm{C}$ in $50 \mathrm{~mm}$ Tris, $\mathrm{pH} 7,125 \mathrm{~mm} \mathrm{NaCl}$, and $0.05 \% \mathrm{BSA}$. Reactions were stopped with thiorphan, and $\mathrm{A} \beta$ was measured using an antibody-based HTRF assay (Cisbio Bioassays) as per the manufacturer's instructions.

Mass spectrometry analysis of $A \beta$ proteolysis. The disappearance of mouse and human $\mathrm{A} \beta_{1-40}$ and $\mathrm{A} \beta_{1-42}$ parent peptides over time in buffer in response to cleavage by mouse Fc-NEP was monitored by multiple reaction monitoring (MRM) on a 4000Qtrap (AB Sciex). The MRM method was developed by first infusing A $\beta$ peptides into a 4000 QTrap using the NanoSpray II source and optimizing instrument parameters (source gases, declustering potential, collision energy, and collision cell exit potential) for the two major charge states and the top five fragment ions for each charge state. $A \beta$ peptides were incubated with $50 \mathrm{~nm}$ human Fc-NEP in activity buffer (50 mM Tris, pH 7.0, $125 \mathrm{~mm} \mathrm{NaCl}, 0.005 \%$ BSA) and aliquots were removed at $0,5,10,15,30,60$, and $120 \mathrm{~min}$, acidified to $0.1 \mathrm{M} \mathrm{HOAc}$, and analyzed by nano-liquid chromatography/ mass spectrometry (nano-LC/MS) with the above MRM method on the 4000 QTrap with vented column setup (Licklider et al., 2002). Samples were loaded and desalted on a $360 \times 200 \mu \mathrm{m}$ precolumn with $3 \mathrm{~cm}$ Poros10R2 (Applied Biosystems) and then placed in-line with a $60 \times 75$ $\mu \mathrm{m}$ integrated tip packed with $1 \mathrm{~cm}$ Poros10R2. Peptides were separated with a 10 min gradient from 0 to $40 \%$ solvent B $(0.1 \%$ HOAc, acetonitrile). Instrument parameters were as follows: quadrupoles Q1 and Q3 set to unit resolution; curtain gas to $20 \mathrm{psig}$ (pounds per square inch gauge); CAD (collisionally activated dissociation) gas to 12 psig; ion spray voltage to $2200 \mathrm{~V}$; interface heater to $140^{\circ} \mathrm{C}$. Peak areas were calculated for the each transition and summed for each peptide. The $30 \mathrm{~min}$ incubation was also analyzed by nano-LC/MS/MS (tandem mass spectrometry) to identify cleavage products from the $\mathrm{A} \beta$ peptides. MRM transitions were developed and optimized for the most abundant peptides, such as the internal sequence peptides YEVHHQKL and FAEDVGSNKGA. The Fc$\mathrm{NEP}, \mathrm{A} \beta$ peptide incubations were repeated and cleaved fragments targeted by nano-LC/MS with MRM as before except that the columns were packed with Monitor C18 (Column Engineering).

In vivo treatment of animals with $\mathrm{Fc}-\mathrm{NEP}$ and sample preparation. All animal studies conformed to Institutional Animal Care and Use Committee-approved protocols. C57BL/6J mice (males, $\sim 8$ weeks old) or APP23 mice (females, 17 months old at the beginning of the study) were dosed intravenously through the tail vein with $200 \mu \mathrm{l}$ of Fc-NEP or the PBS vehicle. Depending on the treatment schedule, retro-orbital bleeds (20-50 $\mu \mathrm{l}$ per mouse) were performed during the course of the treatments to monitor plasma $\mathrm{A} \beta$ and NEP levels. At the end of each study, $600 \mu$ l of blood was collected by retro-orbital bleeding within 1 min while mice were under isoflurane anesthesia using $250 \mu$ l Natelson blood collecting tubes (Fisher Scientific). Mice were then euthanized in a bell jar containing isoflurane anesthetic, and after 3 min cerebral spinal fluid was collected. CSF was collected from the cisterna magna by cutting with a scalpel behind the head and peeling back the skin from the base of the skull to the eyes. A scalpel was used to make a single cut across the muscle directly over the base of the skull that revealed a triangle-shaped pocket covered by a thin membrane. CSF was collected by piercing this membrane with a small $(50 \mu \mathrm{l})$ capillary tube sharpened by pulling it through the flame of a Bunsen burner. One microliter of CSF was diluted $1: 5$ in PBS containing 3\% BSA. Mice were then rinsed with PBS, the skull was carefully opened, the brain removed, and the olfactory bulbs and hindbrain were discarded. The remaining forebrain was divided into halves. One half was immediately frozen on dry ice for biochemical assays, and the other half was fixed in formalin. Blood samples were centrifuged at room temperature for $10 \mathrm{~min}$ at $1400 \times \mathrm{g}$ for volumes over 50 $\mu \mathrm{l}$ or $2 \mathrm{~min}$ for $50 \mu \mathrm{l}$ capillary tubes. Plasma was removed and frozen until processing.

For intracranial injections, mice were anesthetized with isoflurane and a nosecone was used to deliver sufficient isoflurane to maintain the ani$\mathrm{mal}$ at a surgical state as determined by lack of response to a toe pinch. The unshaved skull was gently wiped with betadine or $70 \% \mathrm{EtOH}$. A 100 $\mu \mathrm{l}$ Hamilton syringe was prepared with the correct concentration of Fc-NEP or PBS to deliver the desired dose volume of $10 \mu \mathrm{l}$. The hub of a 30 gauge needle was attached to the syringe with the sharp tip blunted to fit tightly into the end of a slightly smaller diameter Teflon tube. The tube 
A

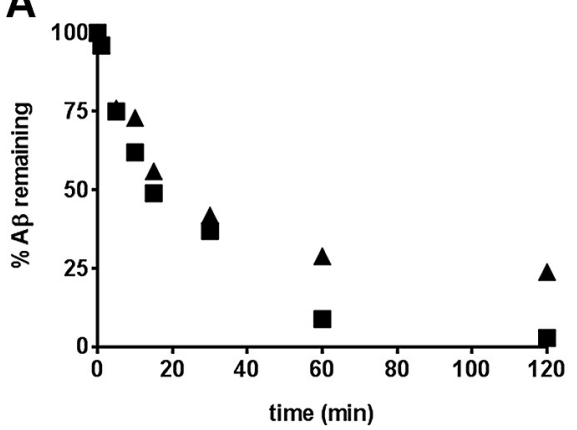

B

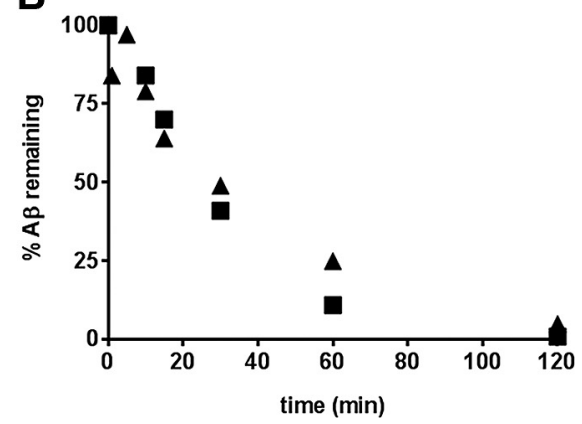

the Endogenous Biotin Blocking Kit (Ventana Medical Systems). Additional blocking was done with the Ventana Antibody Block (Ventana Medical Systems). The Ventana MoMap Mouse on Mouse kit (Ventana Medical Systems) was used to label the primary antibody with biotin. The antibody was incubated for $6 \mathrm{~h}$ at room temperature. The signal was amplified using Ventana AmpMap Kit and then detected with DAB using the Ventana DABMap Kit (Ventana Medical Systems). Slides were coverslipped with permanent mounting media and scanned on a Hamamatsu Nanozoomer. Plaque sizes from 6E10 slides were quantified by Definiens software. Small plaques were defined as those from $23-69 \mu \mathrm{m}$ in diameter, medium-sized plaques $69-230 \mu \mathrm{m}$ in diameter, and large plaques $>230 \mu \mathrm{m}$.

Quantitative PCR measurement of APP expression. RNA was extracted from tissue using

was measured to be long enough to allow for easy reach to the mouse with the syringe resting on the table top. The hub from another 30 gauge needle was removed and the blunt end was inserted into the opposite end of the tubing. The injecting needle was firmly clamped with a straight hemostat and positioned in the grip so that it could only be inserted into the brain at a defined depth of $1.8 \mathrm{~mm}$. The injection needle was placed over the injection site and firmly inserted through the skull into the brain. The needle was held in place with the hemostat, and the opposite hand was used to quickly inject $10 \mu \mathrm{l}$ of Fc-NEP or PBS. After $30 \mathrm{~s}$, to allow for absorption, the needle was slowly removed. Immediately following injection, the animals were removed from anesthesia and placed in a warmed cage until they fully recovered. Any animal displaying seizures or lack of balance was immediately euthanized according to institutional animal welfare guidelines.

Detergent- and formic acid-soluble brain $\mathrm{A} \beta$ fractions were prepared as follows. Dissected brain hemispheres were sonicated in 15 volumes of PBS (137 mM NaCl, $2.7 \mathrm{~mm} \mathrm{KCl,} 15 \mathrm{~mm} \mathrm{Na}_{2} \mathrm{HPO}_{4}{ }^{\star} 2 \mathrm{H}_{2} \mathrm{O}, 1.5 \mathrm{~mm}$ $\mathrm{KH}_{2} \mathrm{PO}_{4}$, pH 7.4) containing protease inhibitor cocktail (Roche Diagnostics). Triton X-100 was added to a final concentration of $1 \%$ and the homogenate was extracted on ice for $15 \mathrm{~min}$, followed by centrifugation at $100,000 \times g$ for $15 \mathrm{~min}$. Supernatant was further diluted by adding an equal volume of ELISA assay buffer ( $50 \mathrm{~mm}$ Tris $\mathrm{pH} 7.5,150 \mathrm{~mm} \mathrm{NaCl}$, $0.02 \%$ Tween $20,3 \%$ BSA). These extracts were also used for measurement of brain Fc-NEP. Formic acid extracts were prepared by adding formic acid to the sonicated brain homogenate to a final concentration of $70 \%(\mathrm{v} / \mathrm{v})$. Samples were placed on ice and vortexed every $5 \mathrm{~min}$ for 15 min, followed by neutralization with 1:20 (v/v) $1 \mathrm{M}$ Tris base with protease inhibitor cocktail. The neutralized extract was centrifuged at $100,000 \times g$ for $15 \mathrm{~min}$ and further diluted with the aforementioned ELISA assay buffer before use in assay.

Measurement of $A \beta$ and $F$ - $-N E P$ protein levels. Mouse plasma and brain $\mathrm{A} \beta_{1-40}$ levels were measured by electrochemiluminescence assay as per the manufacturer's protocols (Meso Scale Discovery). The lower limits of quantitation for plasma and brain homogenate were $\sim 1 \mathrm{pg} / \mathrm{ml}$ and $0.2 \mathrm{pg}$ $\mathrm{A} \beta / \mathrm{mg}$ brain, respectively. Recombinant Fc-NEP levels in plasma and brain samples were measured by ELISA using an anti-NEP capture antibody (R\&D Systems) and anti-mouse IgG detection antibody. Signal was developed using $o$-phenylenediamine dihydrochloride (Sigma) diluted in phosphate citrate buffer (Sigma) and read on a spectrophotometer at $\lambda_{\mathrm{EX}}=450 \mathrm{~nm}$.

Plaque histology. Formalin-fixed brains were processed into paraffin and embedded for coronal sections. Serial sections $(8 \mu \mathrm{m})$ were cut through the whole brain. Every tenth section was stained histochemically with H\&E, Cresyl Violet, and Congo Red as per procedures taken from the Manual of Histologic Staining Methods of the Armed Forces Institute of Pathology (Blakiston). Every tenth section was also stained with the $\beta$-amyloid antibody 6E10 (Covance) at 1:50 dilution on the Discovery XT Immunostainer (Ventana Medical Systems/Roche). Preblocking was done with normal mouse serum (Jackson ImmunoResearch Laboratories) at 1:20 dilution. Endogenous biotin blocking was performed with the RNeasy Mini Kit from Qiagen. TaqMan was performed using the Invitrogen Superscript III Platinum one-step quantitative RT-PCR system with a mouse APP primer/probe kit (Applied Biosystems) in the ABI 7900HT (Applied Biosystems).

Statistics and calculations. In figures using box-and-whiskers plots, the boxes show the median with the box extending from the 25th to 75th percentiles, while the error bars extend to the highest and lowest values. The kinetic parameters $k_{\text {cat }} / K_{\mathrm{m}}$ were determined using the equation $V=$ $\left(k_{\text {cat }} / K_{\mathrm{m}}\right)^{\star} E_{0}{ }^{*}[S]$, when $[S] \ll K_{\mathrm{m}}$, in Prism (GraphPad). Statistical significance was calculated using Student's $t$ test. For experiments using wild-type mice, minimum detectable differences were calculated for pairwise comparisons of vehicle versus treatment groups (power, $80 \%$; significance level, 0.05; two-sided), using NQuerey Advisor 7 software (Statistical Solutions). Effective doses and concentrations of Fc-NEP were calculated using the nonlinear regression sigmoidal dose-response (variable slope) equation in Prism (GraphPad Software). For pharmacokinetic determinations, male C57BL/6J mice ( $\sim 8$ weeks old, 5 mice per dosing group) were dosed intravenously (i.v.) through the tail vein or intraperitoneally (i.p.) with $3.9 \mathrm{mg} / \mathrm{kg}$ (i.v.) or $13.5 \mathrm{mg} / \mathrm{kg}$ (i.p.) of FcNEP. Four to seven plasma samples were collected after i.v. or i.p. dosing, and the concentration of Fc-NEP was determined by activity assay and verified by electrochemiluminescence assay (Mesoscale). The plasma half-life of Fc-NEP was determined by noncompartmental regression analysis using the program WinNonLin (Pharsight Products).

\section{Results}

\section{Recombinant Fc-NEP is active and degrades $A \beta$ in vitro}

NEP is an endogenous protease that degrades $A \beta$. The extracellular, catalytic domain of mouse NEP was expressed and purified as an Fc fusion protein as described in Materials and Methods. Fusing mouse IgG $\mathrm{F}_{1}$ to the N-terminal of NEP produces a fusion construct that resembles the orientation of the native NEP protein in membranes. To determine whether this soluble fusion protein retained proteolytic activity, we measured its catalytic efficiency against the chromogenic peptide substrate Abz-AlaGly-Leu-Ala-paranitroanaline, determining the $k_{\text {cat }} / K_{\mathrm{m}}$ to be $1.0 \times 10^{5} \mathrm{M}^{-1} \mathrm{~s}^{-1}$. The same $k_{\mathrm{cat}} / K_{\mathrm{m}}$ was measured for the extracellular domain of NEP lacking the Fc-fusion.

NEP has previously been reported to cleave $A \beta$ peptides at several locations (Howell et al., 1995; Wang et al., 2006). To verify that the mouse Fc-NEP cleaved both mouse and human $\mathrm{A} \beta_{1-40}$ and $\mathrm{A} \beta_{1-42}$, the peptides were incubated with Fc-NEP and the disappearance of parent was monitored by multiple reaction monitoring mass spectrometry. As expected, both mouse and human $A \beta$ peptides were degraded over time (Fig. 1). Similar results were obtained using electrochemiluminescent $A \beta$ assay (data not shown), demonstrating no differences between direct 


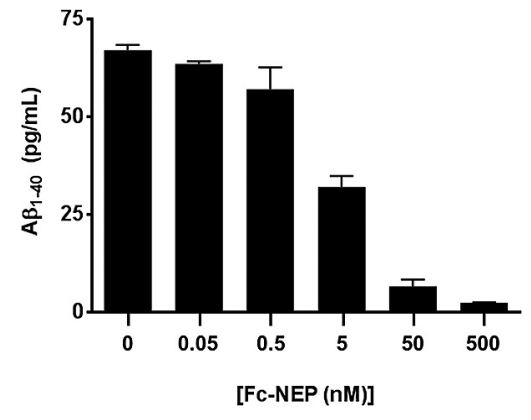

Figure 2. In vitro proteolysis of plasma $A \beta$ by Fc-NEP. Fc-NEP was added to wild-type mouse plasma and incubated at $37^{\circ} \mathrm{C}$ for $90 \mathrm{~min}$, followed by measurement of endogenous mouse $\mathrm{A} \beta_{1-40}$ levels as described in Materials and Methods. Bars represent mean $\pm \mathrm{SD}$ of two replicates.

Table 1. Fc-NEP pharmacokinetics in mouse

\begin{tabular}{lccllcc}
\hline Dose route & Dose $(\mathrm{mg} / \mathrm{kg})$ & $T_{1 / 2}$ (days) & $C_{\max }$ (nm) & $T_{\text {last }}$ (days) & $C_{\text {last }}(\mathrm{nm})$ & $\mathrm{AUC}_{\text {inf }}\left(\mathrm{h}^{*} \mathrm{~nm}\right)$ \\
\hline i.v. & 3.9 & 10 & 180 & 21 & 36 & 55600 \\
i.p. & 13.5 & 9 & 900 & 21 & 140 & 219000 \\
\hline
\end{tabular}

Mice were dosed with FC-NEP and plasma samples were taken 1-21 days later ( $N=5$ mice). Fc-NEP levels were measured by activity assay, and pharmacokinetic parameters were determined as described in Materials and Methods.

measurement (mass spectrometry) and the secondary detection method relied upon in subsequent experiments.

To determine whether similar efficacy would occur under physiologically and therapeutically relevant conditions, Fc-NEP was spiked into plasma from wild-type mice that contained $\sim 70$ $\mathrm{pg} / \mathrm{ml}(16 \mathrm{pm})$ endogenous $\mathrm{A} \beta_{1-40}$, and degradation of the mouse $\mathrm{A} \beta$ was measured after $90 \mathrm{~min}$. As shown in Figure 2, Fc-NEP degraded the mouse $A \beta$ in a concentration-dependent manner, with maximum efficacy observed at $[$ Fc-NEP] $\geq 50 \mathrm{~nm}$. Similar results were observed when Fc-NEP was spiked into plasma from APP23 transgenic mice (data not shown) that produce human $\mathrm{A} \beta$ due to expression of human APP that contains the Swedish double mutation K670N/M671L (Sturchler-Pierrat et al. 1997). By comparison, when Tris buffer is used instead of plasma, a lower concentration of Fc-NEP (10 nM) clears $>90 \%$ of a much higher concentration of mouse $\mathrm{A} \beta_{1-40}(100 \mathrm{nM})$ spiked into the Tris solution (data not shown). The apparent reduced efficiency of Fc-NEP degradation of $A \beta$ in plasma relative to buffer might be caused by the presence of additional NEP substrates in plasma (Llorens-Cortes et al., 1992; Yamamoto et al., 1992; Pignone et al., 2007). Regardless, these in vitro results demonstrate the proteolytic efficacy of Fc-NEP against $\mathrm{A} \beta$.

\section{Fc-NEP has a 10 day half-life in mouse}

To determine whether the Fc-NEP would have a sufficient plasma half-life to enable in vivo studies of $\mathrm{A} \beta$ depletion, the pharmacokinetic parameters of the construct were measured following i.v. or i.p. administration of Fc-NEP to wild-type (WT) mice (Table 1). The half-life in mouse was 9-10 days, long enough for subsequent efficacy studies. Significantly, the primary method of detection was activity-based, meaning that the construct retained its proteolytic activity in vivo over time. Subsequent experiments use both a protein-based NEP ELISA as well as the activity assay to measure NEP concentrations. These two measurement assays were consistent with each other, confirming that the activity is durable and a good approximation of NEP protein levels.

\section{Peripheral Fc-NEP clears peripheral A $\beta$ in vivo, but has no effect on brain $\mathrm{A} \boldsymbol{\beta}$}

The in vivo objective was to completely degrade plasma $\mathrm{A} \beta$ and look for corresponding decreases in the detergent-extractable brain $\mathrm{A} \beta$ fraction, which would suggest a dynamic, nonsaturated equilibrium between the two pools. To determine whether FcNEP would reduce plasma $\mathrm{A} \beta$, we first dosed WT mice with PBS or $55 \mathrm{mg} / \mathrm{kg}$ Fc-NEP i.v. and measured plasma $\mathrm{A} \beta_{1-40} 24$ and $96 \mathrm{~h}$ post-dose (data not shown). We found complete degradation of plasma $\mathrm{A} \beta_{1-40}$ in the NEP group at both time points compared to $74 \pm 10 \mathrm{pg} / \mathrm{ml} \mathrm{A} \beta_{1-40}$ in the PBS group ( $p<0.01, N=5$ /group). This corresponded to plasma Fc-NEP levels of $1800 \pm 170$ and $1270 \pm 90 \mathrm{~nm}$ in the 24 and $96 \mathrm{~h}$ treatment groups, respectively. We attempted to measure $\mathrm{A} \beta_{1-42}$ levels in response to Fc-NEP treatment as well, but the endogenous concentrations in WT mice were below the limit of detection.

We next examined Fc-NEP concentration-response on plasma and brain $\mathrm{A} \beta_{1-40}$ levels at a 14 day time point, chosen to account for the possibility of lag time between plasma and brain $\mathrm{A} \beta$ reduction. As indicated in Figure 3, PBS or different doses of Fc-NEP were given at days 1 and 10, with plasma and brain measurements done at day 14. Dose-dependent clearance of plasma $\mathrm{A} \beta_{1-40}$ was observed (Fig. $3 A$ ), with $\mathrm{A} \beta$ concentrations decreasing from $72 \pm 5 \mathrm{pg} / \mathrm{ml}$ in the PBS group to $42 \pm 6,34 \pm 2,10 \pm$ 1 , and $0 \pm 0.2 \mathrm{pg} / \mathrm{ml}$ in the $0.55,1.65,5.5$, and $55 \mathrm{mg} / \mathrm{kg} \mathrm{Fc-NEP}$ treatment groups, respectively $(p<0.01$ compared to PBS for all NEP groups). Plasma Fc-NEP concentrations were $16 \pm 4,100 \pm$ $20,390 \pm 120$, and $3170 \pm 290 \mathrm{~nm}$ for each NEP-treated group from low to high dose (Fig. $3 B$ ). These values are consistent with the concentrations found in the prior pharmacokinetic experiment, considering that a second Fc-NEP dose was given here after one half-life. The $\mathrm{ED}_{50}$ and $\mathrm{ED}_{90}$ doses using this repeated dose schedule (days 1 and 10) were calculated to be 1.2 and $8.5 \mathrm{mg} / \mathrm{kg}$, respectively, corresponding to plasma Fc-NEP concentrations of 67 and $630 \mathrm{~nm}$. Detergent soluble brain $\mathrm{A} \beta_{1-40}$ was then extracted and measured as described in the Materials and Methods. Surprisingly, there was no corresponding decrease in this brain $\mathrm{A} \beta$ component at any dose when compared to PBS (Fig. $3 C$ ). For example, $A \beta$ levels in the extract from PBS-treated mice were $1.4 \pm 0.1 \mathrm{pg} \mathrm{A} \beta / \mathrm{mg}$ brain, compared to $1.6 \pm 0.1 \mathrm{pg} / \mathrm{mg}$ in the 55 $\mathrm{mg} / \mathrm{kg}$ Fc-NEP treatment group. Interanimal variability (SEM) within each group was approximately $\pm 10 \%$ and was consistent with brain $\mathrm{A} \beta$ measurements from other experiments. The minimum detectable differences that we would have been able to observe for each treatment group versus vehicle were calculated to be as follows: $0.55 \mathrm{mg} / \mathrm{kg}=42.5 \% ; 1.65 \mathrm{mg} / \mathrm{kg}=42.5 \% ; 5.5$ $\mathrm{mg} / \mathrm{kg}=39.1 \% ; 55 \mathrm{mg} / \mathrm{kg}=39.1 \%$ as described in Materials and Methods.

To determine whether the apparent increase in brain $\mathrm{A} \beta$ in the $1.65 \mathrm{mg} / \mathrm{kg}$ Fc-NEP-treated group (Fig. $3 C$ ) was due to Fc$\mathrm{NEP}$ entry into the brain and binding/sequestration to brain $\mathrm{A} \beta$, we looked for evidence of Fc-NEP in the brain. A mouse NEP ELISA was performed on the detergent-soluble brain fraction. No exogenous Fc-NEP was found in samples from this dose group above the $10 \mathrm{pm}$ limit of detection of the assays (data not shown).

To determine whether a longer treatment duration would result in an associated decrease in brain $\mathrm{A} \beta$ levels, a time course study was run in which mice were administered $10 \mathrm{mg} / \mathrm{kg} \mathrm{Fc}$ NEP (slightly above the $\mathrm{ED}_{90}$ dose as determined by plasma $\mathrm{A} \beta$ clearance) every 10 days, and plasma and brain $\mathrm{A} \beta_{1-40}$ levels were measured at days 14, 28, and 35. Despite achieving the expected $>90 \%$ clearance of plasma $\mathrm{A} \beta$ compared to PBS control at each 


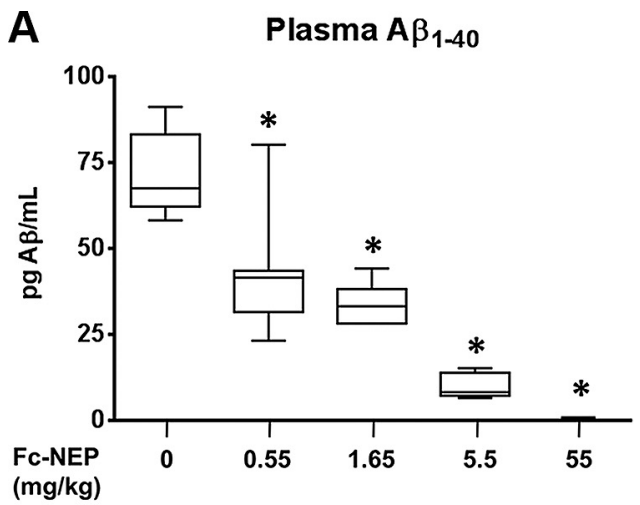

B
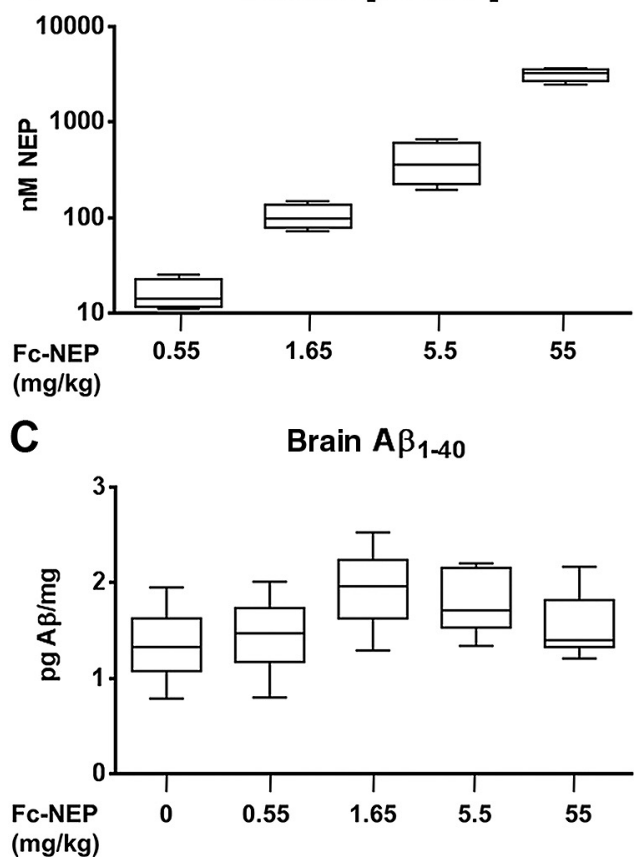

Figure 3. In vivo clearance of $A \beta$ by peripheral FC-NEP. PBS or the indicated doses of FC-NEP were administered to WT mice i.v. at days 1 and $10 . A \beta$ and NEP levels were measured at day 14 as described in the Materials and Methods. $A$, Plasma $A \beta_{1-40}$ was found to be cleared in a dose-dependent manner, with complete clearance observed at the highest dose. $N=8 /$ group and the asterisk $\left(^{*}\right)$ indicates $p<0.01$ compared to PBS. B, Plasma Fc-NEP levels were determined by NEP ELISA and confirmed by activity assay. NEP was not found in the PBS group (not shown). $N=4$ /group. $C$, Triton X-100 soluble brain $A \beta_{1-40}$ was extracted and measured. No decrease was found upon Fc-NEP treatment compared to PBS-treated animals. $N=8 /$ group.

time point ( $p<0.01, N \geq 8$ ), there again was no observed decrease in detergent soluble brain $\mathrm{A} \beta_{1-40}$ (Fig. 4). The $\mathrm{A} \beta_{1-40}$ levels were consistently around $1.5 \mathrm{pg} / \mathrm{mg}$ brain, with standard error around $10 \%$. The minimum detectable difference for each treatment group versus its time-matched PBS control was: 14 days, 21.8\%; 28 days, 32.0\%; 35 days, 10.9\%. Plasma Fc-NEP concentrations at the 14,28 , and 35 day time points were 2250, 2370 , and $2830 \mathrm{nM}$, respectively.

To determine whether $\mathrm{A} \beta$ production might be upregulated in response to chronic exposure to the Fc-NEP construct and is thus masking A $\beta$ clearance in the brain, we looked at APP mRNA levels in the brain from the 14 day time point of WT mice dosed with $10 \mathrm{mg} / \mathrm{kg}$ Fc-NEP or PBS. No difference in APP expression was found between groups ( $n=10$ /group) however, suggesting that there is not compensatory upregulation of gene expression occurring.

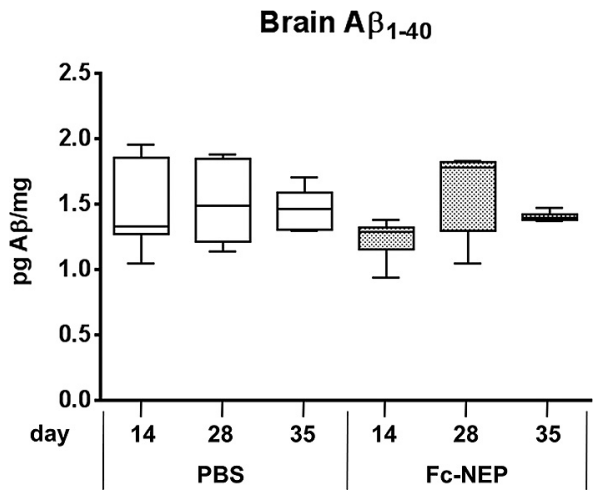

Figure 4. Brain $A \beta$ is not cleared over 35 days with repeated dosing. PBS or Fc-NEP (10 $\mathrm{mg} / \mathrm{kg}$ ) was administered i.v. to WT mice every 10 days. At days 14,28 , and 35 , Triton X-100 soluble brain $A \beta$ was extracted and measured as described in Materials and Methods. $N \geq$ 8/group.

Although our results in WT mice suggested a lack of soluble brain $\mathrm{A} \beta$ reduction in response to increased peripheral $\mathrm{A} \beta$ clearance, we wanted to determine whether there would be an effect on established amyloid plaques in the brain. Therefore, Fc-NEP was tested in APP23 mice, which develop amyloid plaques in the brain as they age due to the production of human $A \beta$. Seventeenmonth-old APP23 mice with high plaque burdens were administered $100 \mathrm{mg} / \mathrm{kg}$ Fc-NEP $\left(\mathrm{ED}_{90}\right.$ dose as determined by plasma $\mathrm{A} \beta$ levels) i.v. every $12-16$ days for 3 months. At the end of the study, soluble plasma and cerebrospinal fluid levels of the human $\mathrm{A} \beta$ produced by the transgene were measured. Amyloid plaque loads were quantified by measuring $A \beta$ in formic acid-extracted brain samples as well as through brain histology. As shown in Figure 5, no decreases in total brain $\mathrm{A} \beta$ or CSF $\mathrm{A} \beta$ were observed despite complete degradation of plasma A $\beta$. Similarly, no significant differences in numbers of large plaques (161 vs 171 for NEP vs PBS), medium plaques (179 vs 178 for NEP vs PBS), or small plaques (284 vs 277 for NEP vs PBS) were found. Fc-NEP levels in the brain at the end of the study were $<1 \mathrm{~nm}$. These data are consistent with our soluble brain $\mathrm{A} \beta$ results in WT mice.

Intracranial injection of $F c-N E P$ acutely reduces soluble brain $A \beta$ To verify that directly augmenting brain amyloid clearance capacity would result in decreased levels of soluble brain $\mathrm{A} \beta, 0.5$ nmol Fc-NEP was administered through intracranial injection to the brains of WT mice. Compared to a PBS control injection, detergent soluble brain $\mathrm{A} \beta$ levels were decreased $46 \%(p=0.04)$ at $1 \mathrm{~h}$ postinjection, but returned to normal between $6-24 \mathrm{~h}$ (Fig. 6). Fc-NEP levels in the brain were found to be 16,60 , and $140 \mathrm{nM}$ in the 3 animals from the $1 \mathrm{~h}$ time point, but were $11 \mathrm{~nm}$ or less at the later time points.

\section{Discussion}

The key findings of this study are as follows. First, we have fused the extracellular catalytic domain of neprilysin with a mouse $\operatorname{IgG}_{1}$ Fc region, resulting in a constitutively active protease that retains activity against $\mathrm{A} \beta$ peptides. This protein has a long half-life characteristic of antibodies, enabling its use in vivo. Second, we have used this Fc-NEP protease to degrade, rather than sequester, plasma $A \beta$ in mice, finding brain $A \beta$ levels unchanged in response. This suggests that the brain-to-plasma clearance mechanisms for $A \beta$ are saturated under normal conditions and that an additional driving force in the form of reduced plasma $\mathrm{A} \beta$ concentrations cannot enhance clearance from brain. Third, we have determined that brain APP expression does not change in re- 
sponse to reduction of peripheral $\mathrm{A} \beta$ concentrations, suggesting that the rate of $A \beta$ production is not tied to changes in plasma $A \beta$. Fourth, we demonstrated that by directly enhancing degradation mechanisms in the brain, levels of brain $\mathrm{A} \beta$ could be lowered, although this clearance is rapidly overcome by the robust production of $\mathrm{A} \beta$.

Plasma $\mathrm{A} \beta$ was degraded by Fc-NEP in a concentration-dependent manner. The higher activity requirements for $\mathrm{A} \beta$ reduction in plasma compared to buffer might be due to the presence of additional NEP substrates, such as atrial natriuretic peptide, in plasma (Llorens-Cortes et al., 1992; Yamamoto et al., 1992; Pignone et al., 2007). The $\mathrm{EC}_{90}$ in vivo was $632 \mathrm{~nm}$, compared to $\sim 50 \mathrm{~nm}$ in vitro. This likely reflects the rapid peripheral turnover of $\mathrm{A} \beta$ and other endogenous NEP substrates, many of which have reported half-lives of only minutes (Yandle et al., 1986; Grouzmann et al., 2001). Nonetheless, our data suggest it was possible to achieve Fc-NEP concentrations in vivo sufficient to maintain animals in a plasma- $\mathrm{A} \beta_{1-40}$ deficient state, thus allowing investigations into the efflux of brain $A \beta$ to the periphery. It should be noted that proteolytic fragments were not tracked in vivo, and thus it remains possible that shorter $A \beta$ isoforms may have been transiently generated during degradation. The MRM analysis of $A \beta$ degradation by Fc-NEP in buffer tracked the disappearance of two internal peptides in the $\mathrm{A} \beta$ sequence, suggesting that further amyloidogenic species are not generated by Fc-NEP activity. However, because the further clearance of such peptide fragments was not followed in vivo, it is unknown whether they influenced $A \beta$ transport/diffusion between compartments.

Surprisingly, soluble brain $\mathrm{A} \beta_{1-40}$ levels did not decrease despite the complete degradation of plasma $\mathrm{A} \beta_{1-40}$. Although we found an apparent increase in brain $\mathrm{A} \beta$ levels in the $1.65 \mathrm{mg} / \mathrm{kg}$ treatment group at the 14 day time point (Fig. $3 B$ ), similar findings were not made at different doses or time points. The lack of evidence for Fc-NEP in the brain or upregulation of APP expression in response to treatment suggests that the upregulation in this single group might be due to variability in extracting and measuring soluble $\mathrm{A} \beta$ pools at concentrations near the lower limits of quantitation for the assays. Our studies analyzed brain homogenate, which is comprised predominantly of cellular $A \beta$, and thus more subtle alterations in brain interstitial fluid could have been masked, particularly with regard to the $40 \%$ minimum detectable difference (MDD) in our acute wild-type mouse studies. With this in mind, we ran longer duration studies to enhance the likelihood of detecting smaller accumulated alterations in brain $A \beta$ levels from such sources. Still, despite a reduction in the MDD to $11 \%$ in the 35 day study, no significant reductions in brain $\mathrm{A} \beta$ were detected. It is also possible that decreases in extracellular brain $\mathrm{A} \beta$ occur, but are masked by decreased cellular degradation of intracellular $A \beta$ followed by equilibration of the pools, since our extraction method does not discern between the two pools. Unfortunately, examination of such cellular trafficking was outside the scope of our studies.

$\mathrm{A} \beta$ concentrations in the peripheral and central compartments are influenced by efflux and influx mechanisms. A number of laboratories have reported transport of $\mathrm{A} \beta$ from the periphery into the brain (Zlokovic et al., 1993; Ghilardi et al., 1996; Poduslo
B

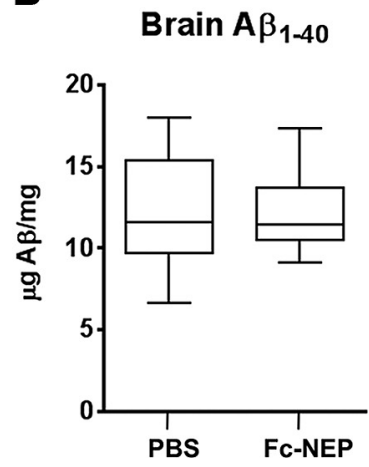

C

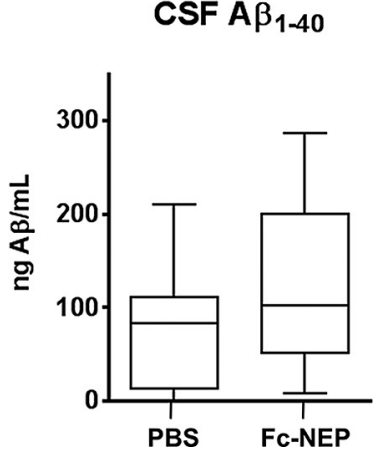

Figure 5. Chronic peripheral dosing of Fc-NEP does not lower brain $A \beta_{1-40}$ in plaque-bearing APP23 mice despite complete peripheral depletion. PBS or Fc-NEP ( $100 \mathrm{mg} / \mathrm{kg}$ ) was administered i.v. to 17 month old APP 23 mice every 2 weeks for 3 months. $\boldsymbol{A}$, acid was used to extract soluble and insoluble brain $A \beta$ ( $N \geq 10 /$ group). C, CSF was extracted and $A \beta$ levels measured ( $N \geq$ $13 /$ group). Outliers greater than $3 \times$ SEM were removed from the analyses.

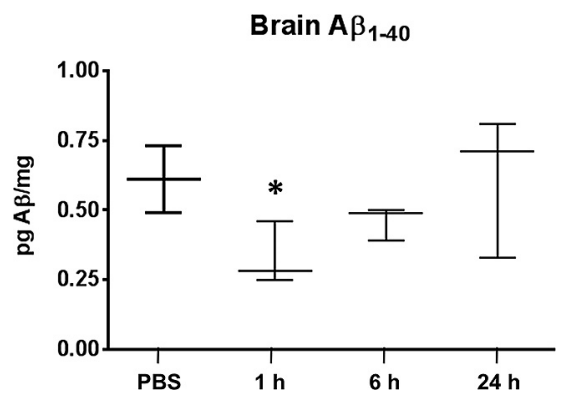

Figure 6. Intracranial delivery of $\mathrm{FC}-\mathrm{NEP}$ reduces brain $\mathrm{A} \beta_{1-40}$ immediately following treatment. PBS or FC-NEP $(6 \mathrm{mg} / \mathrm{ml}, 0.5 \mathrm{nmol})$ were administered to WT mice in $10 \mu$ l solution. NEP-treated samples were taken at 1, 6, and $24 \mathrm{~h}$, and PBS samples were taken at $6 \mathrm{~h}$. Triton $X$-100 soluble brain $A \beta$ was extracted and measured as described in Materials and Methods. $N=3 /$ group. Asterisk $\left(^{*}\right)$ indicates $p=0.04$ compared to the PBS group.

et al., 1997; Mackic et al., 1998) and in the reverse direction, from the brain into the periphery (Ghersi-Egea et al., 1996; Shibata et al., 2000; Cirrito et al., 2005). Movement of $A \beta$ in either direction is dependent on the integrity of the neurovascular unit and is mediated by a number of binding partners and transporter systems, such as LRP-1, RAGE, ApoE, ApoJ, and P-glycoprotein, which are regulated in a complex fashion (for review, see Sagare et al., 2012). The failure to observe decreases in brain $A \beta$ suggests that the basal efflux rate is already at its maximum. Likewise, no Fc-NEP was found in the brain compartment, consistent with an intact blood-brain barrier, BBB, in these healthy WT mice preventing the influx of the exogenous protein. Interestingly, it has previously been reported (Banks et al., 2003; Pascale et al., 2011) that the $A \beta$ efflux capacity decreases further with age, and so improved efficacy of a truly peripherally acting anti- $\mathrm{A} \beta$ therapeutic would not be expected in older animals. Consistent with this, we did not observe decreased total amyloid load or plaque numbers in very old APP23 mice treated for 3 months with FcNEP. Although it may be argued that the plaque burden might have been too high to see an effect in the aged APP23 mice used in the present study, it should be noted that some of the original experiments presented in support of the sink hypothesis were performed in older, plaque-burdened APP transgenic mice (DeMattos et al., 2002), and that efficacy of either passive or active immunization in reducing amyloid burden in aged transgenic mice has been repeatedly demonstrated, particularly in models that deposit predominantly diffuse amyloid (for review, 
see Golde et al., 2009). In such models, reduced amyloid burden has been most sensitively detected by immunohistochemical quantification of small and/or diffuse deposits in comparison to biochemical analysis, as exemplified by passive and active immunization studies with APP23 mice of similar or greater age than those used in the present study (Pfeifer et al., 2002; Wiessner et al., 2011). However, no such effect was detected in histological quantifications in the present study. Our data with NEP suggest that the peripheral immunotherapies, which essentially clear free plasma $\mathrm{A} \beta$ by sequestering it as part of an antibody complex, could be exerting their effects on the brain through a mechanism other than a peripheral sink. Instead, they may be crossing the $\mathrm{BBB}$ and acting directly in the brain. Indeed, it has been shown that the $\mathrm{BBB}$ becomes more permeable in aged transgenic mice overexpressing human A $\beta$ (Paul et al., 2007), as well as in a fraction of the clinical AD population (Bowman et al., 2007). Although levels of such antibodies in the brain have been shown to be very low (Levites et al., 2006), these antibodies might be activating a glial response that leads to increased amyloid clearance by macrophage phagocytosis (Wang et al., 2011). This would be consistent with our results in the aged APP23 mice in which very low levels of Fc-NEP were found in the brain but were not sufficient to directly lower brain $\mathrm{A} \beta$ levels by proteolysis.

Finally, the scope of our studies did not include monitoring levels of soluble $A \beta$ oligomers in the brain. These multimeric species have been implicated in recent years as contributing to the pathogenesis of AD (Shankar et al., 2008). It is not known whether NEP would have a direct proteolytic effect on these oligomers, or whether reduction of the peripheral $A \beta$ pool would subsequently reduce their concentration in the brain. However, this outcome seems unlikely in the absence of corresponding changes in either the soluble monomeric brain $\mathrm{A} \beta$ pool or the overall amyloid plaque burden.

$\mathrm{A} \beta$-neutralizing approaches have been a major focus of $\mathrm{AD}$ research, despite questions about the mechanisms of action preclinically and clinically. Results from studies of these approaches have been inconsistent, both in rodent and in man. Peripherally acting therapeutics are attractive because they simplify administration and control of exposure and offer the use of plasma $A \beta$ as a surrogate biomarker of efficacy. However, our results, combined with a growing body of literature (Golde et al., 2009), suggest that it might not be possible to increase brain $\mathrm{A} \beta$ efflux sufficiently to achieve therapeutic benefit. We have found no evidence for the existence of a robust dynamic equilibrium between plasma and brain $\mathrm{A} \beta$ pools that could be exploited for therapeutic benefit. Indeed, the robust return of brain $A \beta$ levels to normal following direct proteolysis by intracranial NEP further demonstrates the challenge of focusing on $\mathrm{A} \beta$ clearance and suggests that targeting $A \beta$ production will also be important. Efficacy of this type of bimodal strategy was recently suggested by studies in which $\mathrm{A} \beta$ production was impaired in conjunction with anti-amyloid immunotherapy (Wang et al., 2011). This needs to be considered for the future development of $A \beta$-directed therapeutics, since it will likely affect the pharmacokinetic/pharmacodynamic relationship of any such drugs in man.

\section{References}

Banks WA, Robinson SM, Verma S, Morley JE (2003) Efflux of human and mouse amyloid $\beta$ proteins $1-40$ and 1-42 from brain: impairment in a mouse model of Alzheimer's Disease. Neuroscience 121:487-492. CrossRef Medline

Bowman GL, Kaye JA, Moore M, Waichunas D, Carlson NE, Quinn JF (2007) Blood-brain barrier impairment in Alzheimer disease: stability and functional significance. Neurology 68:1809-1814. CrossRef Medline
Cirrito JR, Deane R, Fagan AM, Spinner ML, Parsadanian M, Finn MB, Jiang H, Prior JL, Sagare A, Bales KR, Paul SM, Zlokovic BV, Piwnica-Worms D, Holtzman DM (2005) P-glycoprotein deficiency at the blood-brain barrier increases amyloid-beta deposition in an Alzheimer disease mouse model. J Clin Invest 115:3285-3290. CrossRef Medline

DeMattos RB, Bales KR, Cummins DJ, Dodart JC, Paul SM, Holtzman DM (2001) Peripheral anti-A $\beta$ antibody alters CNS and plasma $A \beta$ clearance and decreases brain $\mathrm{A} \beta$ burden in a mouse model of Alzheimer's disease. Proc Natl Acad Sci U S A 98:8850-8855. CrossRef Medline

DeMattos RB, Bales KR, Cummins DJ, Paul SM, Holtzman DM (2002) Brain to plasma amyloid- $\beta$ efflux: a measure of brain amyloid burden in a mouse model of Alzheimer's disease. Science 295:2264-2267. CrossRef Medline

Ghersi-Egea JF, Gorevic PD, Ghiso J, Frangione B, Patlak CS, Fenstermacher JD (1996) Fate of cerebrospinal fluid-borne amyloid beta-peptide: rapid clearance into blood and appreciable accumulation by cerebral arteries. J Neurochem 67:880-883. CrossRef Medline

Ghilardi JR, Catton M, Stimson ER, Rogers S, Walker LC, Maggio JE, Mantyh PW (1996) Intra-arterial infusion of [125I]Abeta 1-40 labels amyloid deposits in the aged primate brain in vivo. Neuroreport 7:2607-2611. CrossRef Medline

Golde TE, Das P, Levites Y (2009) Quantitative and mechanistic studies of A $\beta$ immunotherapy. CNS Neurol Disord Drug Targets 8:31-49. CrossRef Medline

Grouzmann E, Fathi M, Gillet M, de Torrenté A, Cavadas C, Brunner H, Buclin T (2001) Disappearance rate of catecholamines, total metanephrines, and neuropeptide $\mathrm{Y}$ from the plasma of patients after resection of pheochromocytoma. Clin Chem 47:1075-1082. Medline

Hardy J, Selkoe DJ (2002) The amyloid hypothesis of Alzheimer's disease: progress and problems on the road to therapeutics. Science 297:253-256. CrossRef Medline

Howell S, Nalbantoglu J, Crine P (1995) Neutral endopeptidase can hydrolyze beta-amyloid (1-40) but shows no effect on beta-amyloid precursor protein metabolism. Peptides 16:647-652. CrossRef Medline

Iwata N, Tsubuki S, Takaki Y, Watanabe K, Sekiguchi M, Hosoki E, Kawashima-Morishima M, Lee HJ, Hama E, Sekine-Aizaway Y, Saido TC (2000) Identification of the major $A \beta_{1-42}$-degrading catabolic pathway in brain parenchyma: suppression leads to biochemical and pathological deposition. Nat Med 6:143-150. CrossRef Medline

Iwata N, Tsubuki S, Takaki Y, Shirotani K, Lu B, Gerard NP, Gerard C, Hama E, Lee HJ, and Saido TC (2001) Metabolic regulation of brain A $\beta$ by neprilysin. Science 292:1550-1552. CrossRef Medline

Jankowsky JL, Younkin LH, Gonzales V, Fadale DJ, Slunt HH, Lester HA, Younkin SG, Borchelt DR (2007) Rodent A $\beta$ modulates the solubility and distribution of amyloid deposits in transgenic mice. J Biol Chem 282:22707-22720. CrossRef Medline

Levites Y, Smithson LA, Price RW, Dakin RS, Yuan B, Sierks MR, Kim J, McGowan E, Reed DK, Rosenberry TL, Das P, Golde TE (2006) Insights into the mechanisms of action of anti-Abeta antibodies in Alzheimer's disease mouse models. FASEB J 20:2576-2578. CrossRef Medline

Licklider LJ, Thoreen CC, Peng J, Gygi SP (2002) Automation of nanoscale microcapillary liquid chromatography-tandem mass spectrometry with a vented column. Anal Chem 74:3076-3083. CrossRef Medline

Llorens-Cortes C, Huang H, Vicart P, Gasc JM, Paulin D, Corvol P (1992) Identification and characterization of neutral endopeptidase in endothelial cell from venous and arterial origin. J Biol Chem 267:14012-14018. Medline

Mackic JB, Weiss MH, Miao W, Kirkman E, Ghiso J, Calero M, Bading J, Frangione B, Zlokovic BV (1998) Cerebrovascular accumulation and increased blood-brain barrier permeability to circulating Alzheimer's amyloid beta peptide in aged squirrel monkey with cerebral amyloid angiopathy. J Neurochem 70:210-215. Medline

Marques MA, Kulstada JJ, Savard CE, Green PS, Lee SP, Craft S, Watson GS, Cook DG (2009) Peripheral amyloid- $\beta$ levels regulate amyloid- $\beta$ clearance from the central nervous system. J Alzheimers Dis 16:325-329. CrossRef Medline

Marr RA, Rockenstein E, Mukherjee A, Kindy MS, Hersh LB, Gage FH, Verma IM, Masliah E (2003) Neprilysin gene transfer reduces human amyloid pathology in transgenic mice. J Neurosci 23:1992-1996. Medline

Masters CL, Simms G, Weinman NA, Multhaup G, McDonald BL, Beyreuther K (1985) Amyloid plaque core protein in Alzheimer disease 
and Down syndrome. Proc Natl Acad Sci U S A 82:4245-4249. CrossRef Medline

Pascale CL, Miller MC, Chiu C, Boylan M, Caralopoulos IN, Gonzalez L, Johanson CE, Silverberg GD (2011) Amyloid-beta transporter expression at the blood-CSF barrier is age-dependent. Fluids Barriers CNS 8:21-31. CrossRef Medline

Paul J, Strickland S, Melchor JP (2007) Fibrin deposition accelerates neurovascular damage and neuroinflammation in mouse models of Alzheimer's disease. J Exp Med 204:1999-2008. CrossRef Medline

Pfeifer M, Boncristiano S, Bondolfi L, Stalder A, Deller T, Staufenbiel M, Mathews PM, Jucker M (2002) Cerebral hemorrhage after passive anti-A $\beta$ immunotherapy. Science 298:1379. CrossRef Medline

Pignone A, Del Rosso AD, Brosnihan KB, Perfetto F, Livi R, Fiori G, Guiducci S, Cinelli M, Rogai V, Tempestini A, Bartoli F, Generini S, Ferrario CM, Cerinic MM (2007) Reduced circulating levels of angiotensin-(1-7) in systemic sclerosis: a new pathway in the dysregulation of endothelialdependent vascular tone control. Ann Rheum Dis 66:1305-1310. CrossRef Medline

Poduslo JF, Curran GL, Haggard JJ, Biere AL, Selkoe DJ (1997) Permeability and residual plasma volume of human, Dutch variant, and rat amyloid beta-protein $1-40$ at the blood-brain barrier. Neurobiol Dis $4: 27-34$. CrossRef Medline

Sagare AP, Bell RD, Zlokovic BV (2012) Neurovascular dysfunction and faulty amyloid $\beta$-peptide clearance in Alzheimer disease. Cold Spring Harb Perspect Med 2:a011452. CrossRef Medline

Saito T, Iwata N, Tsubuki S, Takaki Y, Takano J, Huang SM, Suemoto T, Higuchi M, Saido TC (2005) Somatostatin regulates brain amyloid $\beta$ peptide $A \beta 42$ through modulation of proteolytic degradation. Nat Med 11:434-439. CrossRef Medline

Schlaeger EJ, Christensen K (1999) Transient gene expression in mammalian cells grown in serum-free suspension culture. Cytotechnology 30:7183. CrossRef Medline

Shankar GM, Li S, Mehta TH, Garcia-Munoz A, Shepardson NE, Smith I, Brett FM, Farrell MA, Rowan MJ, Lemere CA, Regan CM, Walsh DM, Sabatini BL, Selkoe DJ (2008) Amyloid-beta protein dimers isolated directly from Alzheimer's brains impair synaptic plasticity and memory. Nat Med 14:837-842. CrossRef Medline

Shibata M, Yamada S, Kumar SR, Calero M, Bading J, Frangione B, Holtzman
DM, Miller CA, Strickland DK, Ghiso J, Zlokovic BV (2000) Clearance of Alzheimer's amyloid-b1-40 peptide from brain by LDL receptor-related protein-1 at the blood-brain barrier. J Clin Invest 106:1489-1499. CrossRef Medline

Sturchler-Pierrat C, Abramowski D, Duke M, Wiederhold KH, Mistl C, Rothacher S, Ledermann B, Bürki K, Frey P, Paganetti PA, Waridel C, Calhoun ME, Jucker M, Probst A, Staufenbiel M, Sommer B (1997) Two amyloid precursor protein transgenic mouse models with Alzheimer disease-like pathology. Proc Natl Acad Sci U S A 94:13287-13292. CrossRef Medline

Wang A, Das P, Switzer RC 3rd, Golde TE, Jankowsky JL (2011) Robust amyloid clearance in a mouse model of Alzheimer's Disease provides novel insights into the mechanism of amyloid- $\beta$ immunotherapy. J Neurosci 31:4124-4136. CrossRef Medline

Wang DS, Dickson DW, Malter JS (2006) $\beta$-Amyloid degradation and Alzheimer's disease. J Biomed Biotech 2006:1-12. CrossRef Medline

Wiessner C, Wiederhold KH, Tissot AC, Frey P, Danner S, Jacobson LH, Jennings GT, Lüönd R, Ortmann R, Reichwald J, Zurini M, Mir A, Bachmann MF, Staufenbiel M (2011) The second-generation active Abeta immunotherapy CAD106 reduces amyloid accumulation in APP transgenic mice while minimizing potential side effects. J Neurosci 31:9323-9331. CrossRef Medline

Yamamoto K, Chappell K, Brosnihan KB, Ferrario CM (1992) In vivo metabolism of angiotensin I by neutral endopeptidase (EC3.4.24.11) in spontaneously hypertensive rats. Hypertension 19:1201-1211. Medline

Yandle TG, Richards AM, Nicholls MG, Cuneo R, Espiner EA, Livesey JH (1986) Metabolic clearance rate and plasma half life of alpha-human atrial natriuretic peptide in man. Life Sci 38:1827-1833. CrossRef Medline

Zlokovic BV (2004) Clearing amyloid through the blood-brain barrier. J Neurochem 89:807-811. CrossRef Medline

Zlokovic BV, Ghiso J, Mackic JB, McComb JG, Weiss MH, Frangione B (1993) Blood-brain barrier transport of circulating Alzheimer's amyloid beta. Biochem Biophys Res Com 197:1034-1040. CrossRef Medline

Zou LB, Mouri A, Iwata N, Saido TC, Wang D, Wang MW, Mizoguchi H, Noda Y, Nabeshima T (2006) Inhibition of neprilysin by infusion of thiorphan into the hippocampus causes an accumulation of amyloid $\beta$ and impairment of learning and memory. J Pharm Exp Ther 317:334340. CrossRef Medline 